\title{
ANALISIS FAKTOR-FAKTOR YANG MEMPENGARUHI PRODUKSI INDUSTRI KOPI ROBUSTA DI KECAMATAN WAY TENONG KABUPATEN LAMPUNG BARAT
}

\author{
Robby Alamsyah ${ }^{1}$ Agus Purnomo ${ }^{2}$ \\ Fakultas Ilmu Sosial dan Ilmu Politik, Universitas Bandar Lampung \\ Jl. Zainal Abidin Pagar Alam No.26, Labuhan Ratu, Kedaton, 35142, Bandar Lampung, \\ Indonesia \\ E-mail: \\ obyzipp7@gmail.com \\ agus.purnomo@ubl.ac.id
}

Menjadi penghasil kopi tertinggi di Indonesia, yakni Provinsi Lampung. Kecamatan Way Tenong yang terdapat di Kabupaten Lampung Barat sebagian besar bermata pencaharian penduduk yaitu sebagian petani. Iklim yang mendukung, dan lahan yang strategis memungkinkan besarnya pertumbuhan di bidang pertanian, spesialnya kopi Robusta. Sebagian besar penduduk Kabupaten Lampung Barat bermata pencaharian selaku pemilik perkebunan kopi. Tipe riset yang digunakan dalam riset ini ialah kuantitatif. Populasi dalam studi ini yakni Petani kopi yang terletak di Kecamatan Way Tenong Lampung Barat, ada pula jumlah ilustrasi yang hendak diteliti sebanyak 40 responden petani kopi. Analisis regresi berganda untuk menganalisis pengaruh modal, tenaga kerja, serta luas lahan berpengaruh terhadap penciptaan industri kopi robusta di Kecamatan Way Tenong Lampung Barat. Hasil perhitungan menampilkan kalau F- hitung dan F- tabel, menunjukkan kalau variabel independen mutlak mempengaruhi hasil terhadap variabel dependen.

Kata Kunci: Modal, Tenaga Kerja, Luas Lahan, Industri Kopi Robusta

\section{Pendahuluan}

Kopi menjadi suatu produk utama yang diekspor, kualitas cita rasa kopi Indonesia diakui diseluruh dunia. Biasanya kopi unggulan yang dibudidaya adalah kopi arabika serta kopi robusta. Kopi yang menjadi komoditas budidaya dan komoditas ekspor yang memegang peranan penting dalam perekonomian Indonesia. Indonesia merupakan suatu provinsi yang memproduksi kopi tertinggi di Lampung. Kopi merupakan hasil pertanian Provinsi Lampung, dikarenakan kualitanya. Tepatnya, Kabupaten Lampung Barat menjadi penghasil kopi terbesar di Wilayah Lampung. Berdasarkan statistik (BPS) pada tahun 2014 tentang dibudidaya kopi, wilayah Lampung Barat merupakan penghasil kopi terbesar sebesar 52.546 ton. Selanjutnya di tahun 2015 melonjak menjadi 52.644 ton. Peningkatan hasil produksi kopi tidak lepas dari dukungan serta aspek-aspek yang mempengaruhi penciptaan pertanian, biasanya terbagi menjadi aspek genetik, aspek alam, aspek ketenagakerjaan, aspek permodalan dan aspek pengelolaan.(Yahmadi, 2017). 
Bersumber pada statistik data, menarangkan jika terjadi peningkatan produki. Dari tahun 2009 hingga 2010, volume penjualan Kopi Robusta mengalami penurunan yang cukup signifikan dari 60.446 ton menjadi 27.752 ton, dan di 2011 menghasilkan penurunan yang cukup signifikan. Setelah mengalami penurunan di 2011, mengalami pelonjakan signifikan 61.807 ton di 2012. Sebaliknya, produksi Kopi mengalami penurunan siklus dari tahun 2013 hingga 2014, sedangkan produksi Kopi meningkat stabil dari tahun 2015 hingga 2016. Dari tahun 2017 hingga 2014 dan 2018, produksi kopi menurun menjadi 51. 484,60. Daya produksi panen kopi di Lampung Barat mengalami penurunan, karena minimnya pengetahuan tentang tata cara perawatan kopi robusta.

Dari perspektif proses tersebut, luas lahan, jumlah tenaga kerja, dan jumlah modal yang dibutuhkan untuk pengelolaan kopi penting untuk menunjang proses budidaya kopi. Setiap aspek yang mempengaruhi Produksi kopi robusta adalah luas lahan, jumlah tenaga kerja, dan jumlah modal. Modal dibutuhkan untuk membayar tenaga kerja dan membeli kebutuhan, hibrida, benih, dll. D isisi lain, manusia dituntut untuk mendorong terwujudnya perawatan. Dikarenakan tidak bisa dikelola sendiri, karena memiliki areal tanamnya yang luas. Biasanya selama masa pemeliharaan, petani akan mempekerjakan orang dan pekerja pertanian di sekitar rumah. Jika tidak, mereka mempekerjakan orang dari luar desa. Dari data dan fenomena yang ada, saya sebagai penulis tertarik melakukan penelitian tersebut.

\section{Tinjauan Pusaka}

Kopi Robusta lebih mudah beradaptasi daripada kopi Arabika. Indonesia relatif besar karena dapat digunakan di bagian bawah Daerah tumbuh kuat Kopi robusta. Mempunyai bentuk biji sedikit bulat, lengkung lebih tebal, dan garis tengah yang hampir rata dari bagian atas ke bawah.(Rukmana, 2014).

Beberapa faktor yang berpengaruh kreasi bisa dibagi 2 bagian, di antara lain: 1) Aspek hayati, semacam lahan pertanian dengan tingkatan kesuburan yang berbeda, benih, varietas, pupuk serta obat- obatan. 2) Aspek sosial ekonomi, semacam anggaran penciptaan, harga, angkatan kerja, tingkatan pendidikan, tingkatan pemasukan, pengaruh, ketidakpastian, serta yang lainnya.( Soekartawi, 1990).

Fakor- faktor penciptaan ialah barang ataupun jasa yang disuguhkan oleh alam serta dihasilkan oleh manusia bertujuan untuk menciptakan bermacam- macam ragam benda ataupun jasa. Faktor- faktor penciptaan yang universal digunakan di bidang budidaya adalah lahan, bibit, pupuk, pestisida, tenaga kerja serta lain sebagainya.( Marhasan, 2005).

\section{Metode Penelitian}

Penelitian yang dipilih adalah kuantitatif. Populasinya yaitu seluruh pemilik lahan kopi di Kecamatan Tenong Lampung Barat, Besar sampel yang akan diteliti adalah 40 pemilik lahan kopi. Metode pengumpulan data merupakan faktor penting sehingga Jenis dan sumber data penelitian menjadi menentukan dalam memilih keputusan. Dalam penelitian ini, data diperoleh berdasarkan kuesioner yang dilakukan dengan narasumber. Data utama meliputi identitas orang yang diwawancarai, luas lahan yang mereka miliki, modal yang 
digunakan untuk memproduksi kopi dari lahan yang mereka miliki, pelatihan yang dihadiri oleh narasumber, dan teknologi yang digunakan untuk memberantas hama dan pupuk serta teknologi lain yang digunakan oleh orang yang diwawancarai. Dalam penelitian ini diperoleh data dari Dinas Perkebunan Lampung Barat berupa produksi kopi Robusta dari tahun 2015 sampai tahun 2020 dan persentase kemungkinan peningkatan produksi. Model analisis yang hendak digunakan dalam riset ini merupakan model analisis kualitatif, yang digunakan untuk menganalisis faktor-faktor produksi kopi robusta. Analisis regresi berganda untuk mencari pengaruh permodalan, tenaga kerja, dan luas lahan terhadap produksi kopi robusta di Kecamatan Way Tenong Lampung Barat.

\section{Hasil Dan Pembahasan}

\section{Total Produksi Kopi}

Tabel 1 Produksi Kopi Responden

\begin{tabular}{|c|c|c|c|c|}
\hline Variabel & Mean & SD & $\begin{array}{c}\text { Min- } \\
\text { Max }\end{array}$ & $\begin{array}{c}95 \% \\
\text { CI }\end{array}$ \\
\hline Produksi Kopi & 2,19 & 0,97 & $1,2-$ & $1,86-$ \\
& & & 6,0 & 2,53 \\
\hline
\end{tabular}

Sumber : Data Primer, (Diolah) Tahun 2020

Tabel 1 menunjukkan bahwa petani yang memproduksi kopi terbanyak berada pada kisaran 6 Ton dan yang paling rendah produksinya berkisar 1,2 Ton. Produksi kopi masih dapat ditingkatkan jika digunakan faktor-faktor produksi secara maksimal.

\section{Luas Lahan}

Lahan penanaman kopi di letak studi menggambarkan lahan pribadi. Luas lahan para pemilik yang disurvei di Kabupaten Lampung Barat Kecamatan Way Tenong. Tabel 2 Luas Lahan Petani Kopi

\begin{tabular}{|l|c|c|c|c|}
\hline Variabel & Mean & SD & $\begin{array}{c}\text { Min- } \\
\text { Max }\end{array}$ & $\begin{array}{c}95 \% \\
\text { CI }\end{array}$ \\
\hline Luas Lahan & 2.24 & 0.87 & $\begin{array}{c}1.1- \\
5.0\end{array}$ & $\begin{array}{c}1.94- \\
2.54\end{array}$ \\
\hline
\end{tabular}

Sumber : Data Primer, (Diolah) Tahun 2020

Pada tabel 2 terlihat bahwa luas lahan perkebunan kopi responden yang paling banyak berada pada kisaran 4-5 $\mathrm{Ha}$, sedangkan yang terendah $1,1 \mathrm{Ha}$.

\section{Jumlah Tenaga Kerja}

Tenaga kerja dari 2 sumber perkebunan berasal, yakni tenaga kerja keluarga serta tenaga di luar keluarga, dengan upah Rp.750/liter, serta pekerja tidak dibayar setiap hari, namun dikeluarkan anggaran pada waktu-waktu tertentu. 
Tabel 3 Jumlah Tenaga Kerja Yang Digunakan Petani Kopi

\begin{tabular}{|l|c|c|c|c|}
\hline \multicolumn{1}{|c|}{ Variabel } & Mean & SD & $\begin{array}{c}\text { Min- } \\
\text { Max }\end{array}$ & $\begin{array}{c}95 \% \\
\text { CI }\end{array}$ \\
\hline $\begin{array}{l}\text { Jumlah Tenaga } \\
\text { Kerja }\end{array}$ & 6.3 & 2.85 & $2-16$ & $\begin{array}{c}5.34- \\
7.29\end{array}$ \\
\hline
\end{tabular}

Sumber: Data Primer, (Diolah) Tahun 2020

Terlihat jika jumlah pekerja yang dipekerjakan sangat banyak yaitu kurang lebih 16 orang, serta pekerja paling sedikit kurang lebih 2 orang. Perihal tersebut menunjukkan jika pemanfaatan tenaga kerja dalam budidaya kopi sangat dibutuhkan. Sebab perkebunan kopi terletak di wilayah pegunungan, sehingga perlu perawatan yang baik serta pemakaian pupuk yang tepat untuk menaikkan produksi kopi.

\section{Jumlah Modal}

Modal adalah salah satu faktor terpenting. Modal mengacu pada modal awal, seperti pembelian benih, pembelian pupuk dan biaya tenaga kerja. Dapat dikatakan bahwa penggunaan modal secara langsung serta tidak langsung tujuannya untuk meningkatkan produksi.

Tabel 4. Jumlah Modal yang Digunakan Petani Kopi.

\begin{tabular}{|c|c|c|c|}
\hline Variabel & Mean & SD & Min-Max \\
\hline JumlahModal & Rp 3.838.571 & 1.579 .840 & $1.700 .000-$ \\
& & & 8.000 .000 \\
\hline
\end{tabular}

Sumber: Data Primer, (Diolah) Tahun 2020

\section{Pengaruh Luas Lahan, Jumlah Tenaga Kerja, Dan Jumlah Modal Terhadap Produksi Kopi}

Tabel 5. Hasil Analisis Regresi

Coefficients $^{\mathrm{a}}$

\begin{tabular}{|c|c|c|c|c|c|c|}
\hline \multirow{2}{*}{\multicolumn{2}{|c|}{ Model }} & \multicolumn{2}{|c|}{$\begin{array}{l}\text { Unstandardized } \\
\text { Coefficients }\end{array}$} & \multirow{2}{*}{\begin{tabular}{c|}
$\begin{array}{c}\text { Standardized } \\
\text { Coefficients }\end{array}$ \\
Beta
\end{tabular}} & \multirow[b]{2}{*}{$\mathrm{t}$} & \multirow[b]{2}{*}{ Sig. } \\
\hline & & $B$ & Std. Error & & & \\
\hline \multirow[t]{4}{*}{1} & (Constant) &,- 093 &, 156 & &,- 597 &, 555 \\
\hline & Luas & 287 & 199 & 256 & 1,442 & 159 \\
\hline & Tenaga & 156 & 039 & 455 & 4,039 & 000 \\
\hline & Modal & $1,731 \mathrm{E}-7$ & 000 & 281 & 1,748 & 090 \\
\hline
\end{tabular}

Melalui persamaan regresi linier berganda, bisa diketahui nilai konstanta -0,093 bahwa jika luas lahan, jumlah tenaga kerja, dan jumlah modal konstan maka output kopi (Y) adalah -0,093. Jika diasumsikan variabel independen lain, koefisien regresi X1 (luas lahan) meningkat sebesar 1\%, dan Y (produksi kopi) menurun -0,093, dan seterusnya 


\section{Implikasi Penelitian}

1) Pengaruh Luas Lahan Kepada Produksi Kopi

Uji parsial (uji t) memberikan hasil nilai t sebesar 2,442, koefisien regresi 0,265, dan nilai probabilitas lahan 0,015 (kurang dari 0,05). Hal ini berdampak signifikan kepada produksi kopi, dan t-value 2,442 terlampau kecil dari t-tabel 2.0301. Disimpulkannya yaitu luas lahan berpengaruh signifikan terhadap produksi kopi.

2) Pengaruh Jumlah Tenaga Kerja Kepada Produksi Kopi

Uji parsial (uji t) sentral variabel tenaga kerja dan variabel produksi kopi mengungkapkan nilai t 4,039, koefisien regresi 0,455 , dan nilai probabilitas 0,000 yang artinya tenaga kerja berpengaruh positif serta signifikan kepada tenaga kerja. Untuk produksi kopi nilai $\mathrm{t}$ sejumlah 4,039 lebih besar dari t tabel sebesar 2,0301, Disimpulkannya yaitu jumlah tenaga kerja berpengaruh signifikan terhadap produksi kopi.

3) Pengaruh Jumlah Modal Kepada Produksi Kopi

Uji parsial (uji t) di antara variabel modal dan variabel produksi kopi membuktikan nilai t sejumlah 1,748 , koefisien regresi 0,281 , dan nilai probabilitas 0,090 yang menunjukkan modal berpengaruh positif terhadap kopi. Nilai t tabel 1.748 lebih kecil dari t tabel 2.0301, Disimpulkannya yaitu modal tidak berpengaruh signifikan terhadap produksi kopi.

\section{5. kesimpulan dan saran}

\section{A. Kesimpulan}

1. Luas lahan dan Tenaga kerja berperan mempengaruhi kepada produksi kopi di Kecamatan Way Tenong Kabupaten Lampung Barat.

2. Modal tidak berperan mempengaruhi terhadap produksi kopi di Kecamatan Way Tenong Kabupaten Lampung Barat.Kesimpulan kalkulasi menjelaskan F-hitung > F-tabel, yang menjelaskan independen variabel memegang dampak signifikan kepada variabel dependen.

Saran

1. Petani kopi harus meningkatkan efisiensi penggunaan lahan dan jam kerja untuk meningkatkan produktivitas. Faktanya kopi merupakan komoditas ekspor yang bernilai ekonomi tinggi, peningkatan produksi kopi akan meningkatkan pendapatan masyarakat.

2. Memberikan konsultasi, bimbingan, dan pengetahuan yang lebih mendalam. Sehingga Para Petani kopi, lebih memiliki pengetahuan untuk meningkatkan produksinya 
